\title{
Novel Preparation Technique of Hyperimmune Globulins against Bovine Coronavirus as Surrogate of Beta Coronavirus
}

\author{
Maha Raafat Abd El Fadeel ${ }^{1}$, Ahmad Mohammad Mohammad Allam², Mohamed Fekry Elkersh ${ }^{3,4}$ \\ and Ahmad Mustafa ${ }^{5,6^{*}}$
}

${ }^{1}$ Department of Rinder Pest like Diseases, Veterinary Serum and Vaccine Research Institute, Agriculture Research Center, Cairo, Egypt; ${ }^{2}$ Parasitology and Animals Diseases Department, National Research Centre,33 Bohouth St., Dokki, Giza, P.O. box 12622, Egypt; ${ }^{3}$ Animal Health Institute AHRI, Agriculture research center ARC, Cairo, Egypt. ${ }^{4}$ Ministry of agriculture and land reclamation MALR, Cairo, Egypt; ${ }^{5}$ Faculty of Engineering، October University for Modern Sciences and Arts (MSA)، Giza, Egypt; ${ }^{6}$ Center of Excellencer October University for Modern Sciences and Arts (MSA)، Giza, Egypt

*Corresponding author: ammhamed@msa.edu.eg; chemical_engineer93@yahoo.com

\begin{abstract}
Article History: 21-297 Received: 28-Mar-21 $\quad$ Revised: 6-May-21 Accepted: 22-May-21
\section{ABSTRACT}

Consuming time and effort to prepare hyperimmune globulins using Freund's adjuvant is a sophisticated and harsh technique. In this work, a novel, safe, and rabid method was proposed using monolaurin as an immune-stimulating agent in hyperimmune globulins production against Bovine coronavirus (BCoV). The mentioned virus was used as a surrogate to family Betacoronavirus. Bovine coronavirus (Mabus strain) with titer $\log _{10} 5.8$ tissue culture infective dose infectivity $\left(\mathrm{TCID}_{50}\right) / \mathrm{ml}$ was used in this experiment. The inactivation of the virus was done using $1 \%$ ascorbic acid for $24 \mathrm{~h}$. Monolaurin emulsion $(10 \% \mathrm{w} / \mathrm{v})$ of was prepared by sonication using tween 20 and water. The inactivated bovine coronavirus was added to the emulsion by $20 \%$ of the final volume. The immunoglobulins were prepared by inoculating the inactivated virus with the adjuvant in rabbits and evaluated on the Madin-Darby bovine kidney (MDBK) cell line by virus neutralization test (VNT). The effect of the adjuvant was assessed by histopathological examination of vital organs such as the kidney and liver. The antibody titer against the BCoV was reached its peak, $\log _{2} 1024 \mathrm{TCID}_{50} / \mathrm{ml}$, at the $3 \mathrm{rd}$-week post-inoculation in the rabbits. The level of the globulin reached a high level and its peak $(14.3 \mathrm{~g} / \mathrm{dL})$ at the end of the experiment. No abnormalities were seen in the livers and kidneys of the negative control group of rabbits. Monolaurin showed a new level of safety and efficacy when used as an adjuvant during the preparation of the immunoglobulins against $\mathrm{BCoV}$.
\end{abstract}

Key words: Monolaurin; Hyperimmune Globulins; Bovine coronavirus; Freund's adjuvant.

(C202I IJVS - All Rights Reserved

\section{INTRODUCTION}

The development of novel and rabid techniques for diagnosing epidemiological emergencies is certainly the best enduring and well-trusted immunological approach. Apart from the cost of producing antisera in related species, such antisera are more likely to give non-specific positive results than antibodies raised in non-related species such as the rabbit (Obi et al. 1990). For decades, from the practical scope, the hyperimmune sera's preparation to diagnose viral diseases is considered a fundamental approach in developing direct or indirect kits (Abdel Hady et al. 2012). The time consumed and the efforts expended in manufacturing hyperimmune serum using Freund's adjuvant is considered a wasting utility, especially since this type of adjuvants has a question mark on its safety (Gould-Fogerite and Mannino 2000).

In the mid-1960s, monolaurin used in the nutrition formulation for the first time. Currently monolaurin is globally used as dietary supplement for supporting the immune system. It also provides intestinal flora healthy balance and beneficial levels of yeast (Abdelmoez and Mustafa 2014). The applications of monolaurin extended to be associated with disorders variety such as influenza, common cold, and swine flu (Mustafa et al. 2016). Monolaurin (also called glycerin monolaurate) is a liposomal natural immune stimulant. It is synthesized through the esterification between glycerin and lauric acid

Cite This Article as: El Fadeel MRA, Allam AMM, Elkersh MF and Mustafa A, 2021. Novel preparation technique of hyperimmune globulins against bovine coronavirus as surrogate of beta coronavirus. International Journal of Veterinary Science 10(4): 340-343. https://doi.org/10.47278/journal.ijvs/2021.065 
in the presence of selective catalyst (Abdelmoez et al. 2013). Lauric acid is a saturated naturally occurring fatty acids contains twelve carbon atoms. Coconut oil and palm kernel oil are the richest sources of lauric acid (Hosney et al. 2020; Hosney and Mustafa 2020). It is known that the body can convert lauric acid into monolaurin by the action of enzymes, however it is not known the extent of this conversion actually occurs in vivo (Mustafa et al. 2016). Many studies tested its antibacterial efficacy besides its role as an adjuvant in various vaccines (Peterson and Schlievert 2006).

\section{MATERIALS AND METHODS}

Globally, epidemics of coronavirus starting from severe acute respiratory syndrome (SARS) caused by (SARS-CoV) (Chan 2004), middle East Respiratory Syndrome (MERS) caused by (MERS-CoV) (Zaki et al. 2012), the newly discovered devastating epidemic Coronavirus disease 2019 (COVID-19) caused by severe acute respiratory syndrome coronavirus 2 (SARS-CoV-2) (WHO 2020) urges the need of cheap available diagnostic method. All these strains share the same antigenicity with minimal variations with the Bovine coronavirus (BCoV) (Woo et al. 2009; Nakagawa and Miyazawa 2020).

This work aimed to produce the Bovine coronavirus (BCoV) hyperimmune sera from the purified coronavirus in rabbits using a novel natural immune-stimulating liposome locally prepared named monolaurin.

\section{Ethical Approval}

This study was approved to the ethical standards used in this study and, the relevant national and institutional guidelines on the care and use of laboratory animals were approved by the Medical and Veterinary Research Ethics Committee at the lab animal facility at the Veterinary Serum and Vaccine Research Institute (VSVRI), Cairo, Egypt.

\section{Rabbits}

Six male New Zealand White rabbits weighing approximately $2.0 \mathrm{~kg}$ were used for the in vivo preparation of the hyperimmune serum against Bovine coronavirus. Rabbits were kept in the lab animal facility at VSVRI. All rabbits were monitored for one month. At the end of the experiment, the rabbits were euthanized by carbon dioxide gas asphyxiation with extra confirmation of death by head dislocation, according to the American Veterinary Medical Association guidelines for the euthanasia of animals (Leary et al. 2013).

\footnotetext{
Bovine coronavirus Strain, Propagation and Inactivation

BCoV (Mabus strain) with infectivity titer $\log _{10} 5.8$ $\mathrm{TCID}_{50} / \mathrm{ml}$ (50\% tissue culture infective dose), according to Spearman and Karber (Cottral 1978). The virus was kindly provided by the VSVRI, Ministry of Agriculture, Cairo, Egypt. The obtained virus was used in rabbit's inoculation, virus titration and evaluation of the produced immunoglobulins. The virus was propagated on the Madin-Darby bovine kidney cell (MDBK) cell line according to (Lefèvre and Diallo 1990). The inactivation
}

of $\mathrm{BCoV}$ was according to (Madhusudana et al. 2004) with modifications by using $1 \%$ ascorbic acid for $24 \mathrm{~h}$.

\section{Preparation of Hyperimmune Serum against Bovine Coronavirus}

In brief, $1 \mathrm{~g}$ of $10 \% \mathrm{w} / \mathrm{v}$ monolaurin emulsion, which is locally prepared according to (Mustafa et al. 2016) was dissolved in double-distilled water (DDW) and $1 \mathrm{ml}$ of tween 20 as an emulsifier. The sonication of the prepared emulsion was done at $70 \%$ for $1 / 2 \mathrm{~h}$ and then sterilized by autoclaving. Then, the inactivated $\mathrm{BCoV}$ was added to the emulsion by $20 \%$ of the final volume.

\section{Inoculation of the Immunoglobulins in Rabbits}

The rabbits were divided into two equal groups (every three animals). The first group was injected one time intramuscularly with $0.5 \mathrm{ml}$ of the prepared immunoglobulins. The second group (control negative) was injected with sterile saline in the same manner as the first group. All animals were kept for one month. Sera were collected to evaluate the titer of antibodies on the 1st, 2nd, and 3rd weeks post-inoculation. Afterward, all rabbits were euthanized, and the plain blood was collected in sterile plain vacutainer tubes. The collected blood was left in $4^{\circ} \mathrm{C}$ overnight to let the separation of serum. The tubes were centrifuged at $1500 \mathrm{xg} / 30$ minutes; then, the sera were collected in sterile falcon tubes and kept at $20^{\circ} \mathrm{C}$ till conduct its evaluation.

\section{Evaluation of the prepared hyperimmune sera}

The purity of the prepared immunoglobulins was investigated according to (Stear 2005). The titer of the prepared immunoglobulins was measured by the virus neutralization test $(\mathrm{VNT})$ on $1^{\text {st }}, 2^{\text {nd }}$ and $3^{\text {rd }}$ week's postinoculation according to (Robson et al. 1960). Finally, the estimation of the total protein was carried out according to (Abdel Hady et al. 2012).

\section{Histopathological examination}

The livers and kidneys were retrieved and fixed in $10 \%$ neutral buffered formalin for further pathological examination. Paraffin tissue sections at 4-6 $\mu \mathrm{m}$ thickness were prepared and stained with hematoxylin and eosin for histopathological examination. Histological slides were examined by light microscopy (Bancroft and Layton 2013).

\section{Statistical analysis}

The statistics was run by using T-test to compare between the injected group of animals and the control group where $\mathrm{P} \leq 0.05$ is significant. The test was run by using EXCEL Microsoft program, USA, 2016.

\section{RESULTS AND DISCUSSION}

The antibody titer against the $\mathrm{BCoV}$ (Table 1) was reached its peak, $\log _{2} 1024 \mathrm{TCID}_{50} / \mathrm{ml}$, at the $3^{\text {rd }}$ week post inoculation in the rabbits. The level of the globulin (Table 2) reached the high level and its peak $(14.3 \mathrm{~g} / \mathrm{dL})$ at the end of the experiment. There was significance between the infected and control group $(\mathrm{P} \leq 0.05)$. 
Table 1: Mean antibody titers against bovine coronavirus prepared hyperimmune serum expressed in $\log _{2}$ of TCID $50 / \mathrm{ml}$.

\begin{tabular}{lcccc} 
& 0 day & $1^{\text {st }}$ WPI & $2^{\text {nd }}$ WPI & $3^{\text {rd }}$ WPI \\
\hline Titre & $<2$ & 4 & 32 & 1024 \\
Index & $<0.3$ & 0.6 & 1.5 & 3 \\
\hline
\end{tabular}

WPI: weeks post inoculation.

Table 2: Mean serum protein, albumin, and globulin in the prepared hyperimmune sera against bovine coronavirus at the end of the experiment.

\begin{tabular}{lcc}
\hline $\begin{array}{l}\text { Serum protein } \\
(\mathrm{g} / \mathrm{dL})\end{array}$ & $\begin{array}{c}\text { BCoV } \\
\text { hyperimmune serum }\end{array}$ & $\begin{array}{c}\text { Serum collected from } \\
\text { the control group }\end{array}$ \\
\hline Total protein & 15 & 1 \\
Albumin & 0.7 & 0.65 \\
Globulin & 14.3 & 0.35 \\
\hline
\end{tabular}

Liver cells of non-injected rabbits showed normal hepatocytes, portal tract, and blood sinusoids (Fig. 1a). On the other side, the liver tissue of injected rabbits with the prepared immunoglobulin against $\mathrm{BCoV}$ showed infiltration of inflammatory cells around the portal vein (Fig. 1b). Kidneys of the non-injected animals (Fig. 2a) showed normal renal glomeruli and renal tubules while in injected rabbits with prepared immunoglobulins showed patches of hemorrhage (Fig. 2b).

The use of the hyperimmune globulins produced against viruses is considered a direct and accurate method in diagnosing many viruses. Immunoglobulins are used in the treatment and the rabid diagnosis in times of emergencies (Cunha et al. 2020). This study aimed to produce immunoglobulins against bovine coronavirus as a model of family Beta Coronavirus. The produced immunoglobulins were assessed in rabbits.
The usage of $1 \%$ ascorbic acid with Bovine coronavirus showed effective inactivation. Inactivation was consistent with that of (Turner 1964; Madhusudana et al. 2004) who used ascorbic acid with or without copper sulfate. After inactivation, the virus kept its effectiveness and retained its potency where it gave a high titer (1024 TCID50/ml) even after three weeks of inoculation in the MDBK cell line. Other inactivating agents such as beta propiolactone (BPL) are expensive and potentially carcinogenic, where others such as formaldehyde and phenol are not only inactivating the virus but also adversely affect its antigenicity (Nietert et al. 1974).

Previous works used Freund's adjuvant to prepare hyperimmune sera against the coronaviruses (da Costa et al. 2021). However, it had a wide range of adverse effects, which is enough to restrict its use to experimental immunology in laboratory animals (Batista-Duharte et al. 2011). In this study, the usage of monolaurin ester emulsion as an adjuvant gave a longer immune response with a higher titer. On the other hand, the effects on the vital organs, it was observed hemorrhagic patches in the tissue of kidneys. These results are not in accordance with that reported by (Cetin et al. 2008; Seleem et al. 2018). The results obtained from both works showed no effect of both monolaurin and ascorbic acid on kidney and liver tissues. Our results may be attributed to the usage of different concentrations of both materials. All these results reinforce the idea of the safe effect of the use of monolaurin as adjuvants in experimental immunology studies.
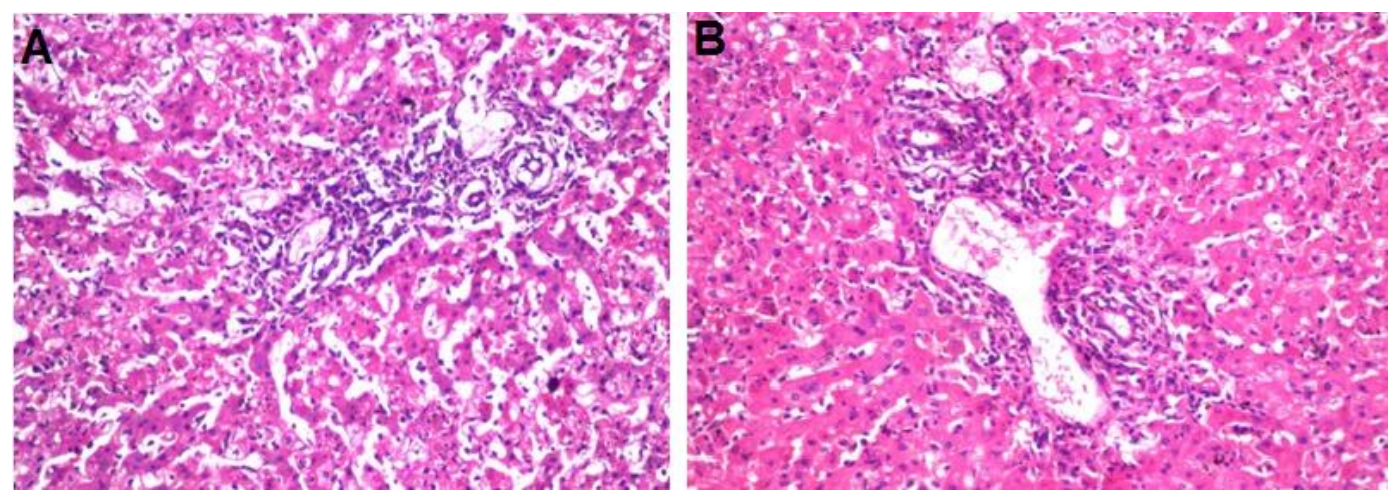

Fig. 1: (A) Liver cells of non-injected rabbits showing normal hepatocytes, portal tract, and blood sinusoids. (B) Liver tissue of injected rabbits showing inflammatory cells infiltration around the portal vein (H\&E) (X 400).
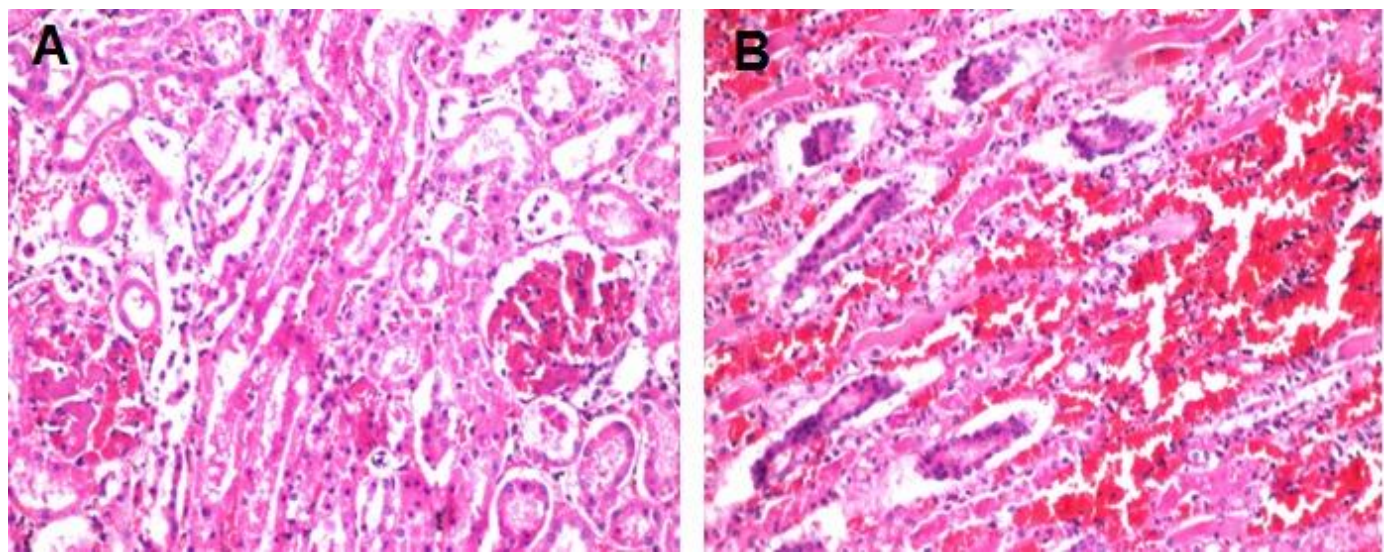

Fig. 2: (A) Kidneys of non-injected rabbits showing normal renal glomeruli and renal tubules. (B) Kidney tissue of injected rabbits showing patches of hemorrhage (H\&E) (X 400). 


\section{Conclusion}

Monolaurin showed a new level of safety as well as efficacy when used as an adjuvant during the preparation of the immunoglobulins against $\mathrm{BCoV}$. The usage of ascorbic acid would be safe and effective when used in the inactivation of the $\mathrm{BCoV}$. However, more investigations should be done on both agents with different concentrations to stand on the safe concentration. We do recommend the usage of monolaurin as an adjuvant in the process of production of $\mathrm{BCoV}$ immunoglobulins.

\section{Author's Contribution}

All authors contributed equally to the manuscript.

\section{REFERENCES}

Abdel Hady M, Effat LE and Albehwar AM, 2012. Preparation of fluorescin conjugated antisera against bovine rota and corona viruses. Zagazig Veterinary Journal 40: 120-124.

Abdelmoez W, Mostafa, N and Mustafa A, 2013. Utilization of oleochemical industry residues as substrates for lipase production for enzymatic sunflower oil hydrolysis. Journal of Cleaner Production 59: 290-297. https://doi.org/10.1016/ j.jclepro.2013.06.032

Abdelmoez W and Mustafa A, 2014. Oleochemical industry future through biotechnology. Journal of Oleo Science 63: 545-554. http://doi.org/10.5650/jos.ess14022

Bancroft $\mathbf{J}$ and Layton C, 2013. The Hematoxylin and eosin In: Suvarna S. Theory Practice of histological techniques, 7 th Ed. edn Philadelphia: Churchill Livingstone of El Sevier, Philadelphia, USA, pp:165-170.

Batista-Duharte A, Lindblad EB and Oviedo-Orta E, 2011. Progress in understanding adjuvant immunotoxicity mechanisms. Toxicology Letters 203: 97-105. http://doi.org/10.1016/j.toxlet.2011.03.001

Cetin M, Devrim E, Serin Kiliçoglu S, Ergüder IB, Namuslu M, Cetin R and Durak I, 2008. Ionic high-osmolar contrast medium causes oxidant stress in kidney tissue: partial protective role of ascorbic acid. Renal Failure, 30:567-572. https://doi.org/10.1080/08860220802064739

Chan PK, To WK, Ng, KC, Lam RK, Ng TK, Chan RC, Wu A, $\mathrm{Yu}$ WC, Lee $\mathrm{N}$ and Hui DS, 2004. Laboratory diagnosis of SARS. Emerging Infectious Diseases 10: 825-831. http://doi.org/10.3201/eid1005.030682

Cottral GE, 1978. Manual of standardized methods for veterinary microbiology, National Research Council. Subcommittee on Standardized Methods.

Cunha LER, Stolet AA, Strauch MA, Pereira VA, Dumard CH, Souza PN, Fonseca JG, Pontes FE, Meirelles LG and Albuquerque JW, 2020. Equine hyperimmune globulin raised against the SARS-CoV-2 spike glycoprotein has extremely high neutralizing titers. BioRxiv. https://doi.org/10.1101/2020.08.17.254375

da Costa CB, Martins FJ, da Cunha LE, Ratcliffe NA, de Paula RC and Castro HC, 2021. COVID-19 and Hyperimmune sera: A feasible plan B to fight against coronavirus. International Immunopharmacology 90: 107-220. http://doi.org/10.1016/j.intimp.2020.107220

Gould-Fogerite $\mathrm{S}$ and Mannino $\mathrm{R}$, 2000. In Methods in Molecular Medicine, Vol. 42, Vaccine Adjuvants: Preparation Methods and Research Protocols, ed. by O'Hagan, DT, Humana Press, Totowa, USA.
Hosney H, Al-Sakkari EG and Mustafa A, 2020. Kinetics and gibbs function studies on lipase-catalyzed production of non-phthalate plasticizer. Journal of Oleo Science 69: 727735. http://doi.org/10.5650/jos.ess20025

Hosney H and Mustafa A, 2020. Semi-continuous Production of 2-Ethyl Hexyl Ester in a Packed Bed Reactor: Optimization and Economic Evaluation. Journal of Oleo Science 69: 3141. http://doi.org/10.5650/jos.ess19229

Leary SL, Underwood W, Anthony R, Cartner S, Corey D, Grandin T, Greenacre C, Gwaltney-Brant S, McCrackin M and Meyer R, 2013. AVMA guidelines for the euthanasia of animals: 2013 edition, American Veterinary Medical Association Schaumburg, IL.

Lefèvre PC, and Diallo A, 1990. Peste des petits ruminants. Revue scientifique et technique (International Office of Epizootics), 9: 935-981. http://doi.org/10.20506/rst.9.4.532

Madhusudana SN, Shamsundar R and Seetharaman S, 2004. In vitro inactivation of the rabies virus by ascorbic acid. International Journal of Infectious Diseases 8: 21-25. http://doi.org/10.1016/j.ijid.2003.09.002

Mustafa A, Karmali A and Abdelmoez W, 2016. Optimisation and economic assessment of lipase-catalysed production of monoesters using Rhizomucor miehei lipase in a solventfree system. Journal of Cleaner Production 137: 953-964. http://doi.org/10.1016/j.jclepro.2016.07.056

Nakagawa S and Miyazawa T, 2020. Genome evolution of SARS-CoV-2 and its virological characteristics. Inflammation and Regeneration 40: 1-7. http://doi.org/ 10.1186/s41232-020-00126-7

Nietert W, Kellicutt L and Kubinski H, 1974. DNA-protein complexes produced by a carcinogen, $\beta$-propiolactone. Cancer Research 34: 859-864.

Obi T, McCullough K and Taylor W, 1990. The production of peste des petits ruminants hyperimmune sera in rabbits and their application in virus diagnosis. Journal of Veterinary Medicine, Series B 37: 345-352. https://doi.org/10.1111/ j.1439-0450.1990.tb01068.x

WHO, 2020. Coronavirus disease ( COVID-19).

Peterson ML and Schlievert PM, 2006. Glycerol monolaurate inhibits the effects of Gram-positive select agents on eukaryotic cells. Biochemistry 45: 2387-2397. http://doi.org/10.1021/bi051992u

Robson D, Gillespie J and Baker J, 1960. The neutralization test as an indicator of immunity to virus diarrhea. Cornell Veterinarian 50: 503-509.

Seleem D, Freitas-Blanco VS, Noguti J, Zancope BR, Pardi V and Murata RM, 2018. In Vivo Antifungal Activity of Monolaurin against Candida albicans Biofilms. Biological and Pharmaceutical Bulletin, 41: 1299-1302. https://doi.org/10.1248/bpb.b18-00256

Stear M, 2005. OIE Manual of Diagnostic Tests and Vaccines for Terrestrial Animals (Mammals, Birds and Bees), 5th Ed. World Organization for Animal Health 2004.

Turner G, 1964. Inactivation of vaccinia virus by ascorbic acid. Microbiology 35: 75-80.

Woo PC, Lau SK, Huang Y and Yuen KY, 2009. Coronavirus diversity, phylogeny and interspecies jumping. Experimental Biology and Medicine 234: 1117-1127. http://doi.org/10.3181/0903-MR-94

Zaki AM, Van Boheemen S, Bestebroer TM, Osterhaus AD and Fouchier RA, 2012. Isolation of a novel coronavirus from a man with pneumonia in Saudi Arabia. New England Journal of Medicine 367: 1814-1820. http://doi.org/ $\underline{10.1056 / N E J M o a 1211721 ~}$ 